\title{
МИРОВОЙ ОПЫТ РЕАЛИЗАЦИИ КЛАСТЕРНОЙ СТРАТЕГИИ РАЗВИТИЯ ТЕКСТИЛЬНОЙ ПРОМЫШЛЕННОСТИ
}

\author{
к.э.н., дои. Х. М. Мавлянбердиева, Ташкентский институт текстильной и лёгкой \\ промышленности, Узбекистан \\ магистр У. Д. Муминова, Ташкентский институт текстильной и лёгкой промышленности, \\ Узбекистан
}

\section{DOI: https://doi.org/10.31435/rsglobal_conf/25062021/7603}

\begin{abstract}
The article provides an analysis of the world experience in the implementation of the cluster strategy for the development of the textile industry and the possibility of applying this experience in the conditions of Uzbekistan.
\end{abstract}

Keywords: cluster, cotton industry, experience of countries, development strategy, cluster in Uzbekistan, economic development, textile industry.

В настоящее время инструментами интенсификации экономики является промышленные кластеры, технопарки и особые экономические зоны. На протяжении всего нескольких десятилетий было образовано большое количество их видов, из которых в итоге выделились наиболее успешные и распространённые, занявшие своё место в инновационных системах как экономически развитых государств, так и ряда динамично развивающихся азиатских стран (таких как Гонконг, Сингапур, Китай, Индия, Южная Корея, Тайвань и других)

Опыт развитых стран показывает, что на первом этапе формирование инновационной экономики важно эффективно развивать и четыре базовых компонента:

- научные и инжиниринговые организации, использующие мировой опыт и знания;

- доступ компаний к информации с низкими издержками;

- образование и навыки населения, способного работать с новым оборудованием и производить конкурентоспособную продукцию;

- деловая среда, стимулирующая отечественные и иностранные предприятия для создания новых и использования существующих технологий (1)

Разработка и внедрение наукоёмких технологий на базе фундаментальных и прикладных научных исследований с использованием приоритетных решений, эффективного использования сырьевых решений (хлопка, шерсти, кожаного и мехового сырья) стало основой формирования новых технологической промышленности.

В начале 90-х годов кластеры были широко признаны как важный элемент стимулирования производительности труда в промышленности и инновационного потенциала предприятий.

С помощью кластеров можно создать технологический базис, включающий совокупные «прорывные технологии» радикальное обеспечение эффективного соответствия объёмов производства, качества и ассортимента продукции совокупному спросу потребителей, повышения национальной значимости конкурентоспособности отрасли и её имиджа в мировом сообществе.

Кластерная политика объединяет не только отраслевую и региональную политику, но и инвестиционную, инновационную, кадровую и социальную политику. То есть кластерный подход является не дополнительным инструментом государственного и регионального управления, а новым подходом к уже имеющимся инструмента. В этом случае содержание промышленной политики меняется от поддержки отдельных предприятий к развитию взаимоотношений между хозяйственными субъектами. Инструментом, реализующим такой кластерной политики может стать программа поддержки развития кластеров. Например как в Финляндии (1994 г), Германии (1996 г), Великобритании (1999 г). Развитие в этих странах так же способствовало создание Европейского кластерного меморандума стран-членов ЕС (2006 г).

Пример кластерного развития за последние сто лет показала Германия, где ставка была сделана на отраслевую консолидацию. Так, в Германии объединялись машиностроительные и сталелитейные предприятия, в Сингапуре- микроэлектронные и нефтехимические, в США - 
компьютерные и автомобильные. Подходы реализации кластерной стратегии в различных странах отражены в таблице 1.

Таблица 1. Мировой опыт реализации кластерной стратегии развития.

\begin{tabular}{|c|c|c|c|}
\hline Страна & Государство & Предприятия & $\begin{array}{l}\text { Наиболее развитые } \\
\text { кластеры }\end{array}$ \\
\hline США & $\begin{array}{l}\text { 1. Развитие научно } \\
\text { технологических } \\
\text { партнёрств. } \\
2 . \quad \text { Предоставление } \\
\text { кредитов и льготного } \\
\text { налогообложения компаний, } \\
\text { осуществляющих } \\
\text { программы НИОКР } \\
\text { 3. Привлечение } \\
\text { первоначального капитала }\end{array}$ & $\begin{array}{l}\text { Концентрация } \\
\text { предприятий в } \\
\text { одном регионе и } \\
\text { максимальное } \\
\text { использование } \\
\text { природного, } \\
\text { научного, кадрового } \\
\text { и интеграционного } \\
\text { потенциала. }\end{array}$ & $\begin{array}{l}\text { Кластеры } \\
\text { информационных } \\
\text { технологий, } \\
\text { киноиндустрийный, } \\
\text { автомобильный, } \\
\text { аэрокосмический }\end{array}$ \\
\hline Япония & $\begin{array}{l}\text { 1. Поощрение развития } \\
\text { узкоспециализированных } \\
\text { регионов } \\
2 . \quad \text { Привлечение из-за } \\
\text { рубежа современных } \\
\text { технологий }\end{array}$ & $\begin{array}{l}\text { Концентрация } \\
\text { средних и мелких } \\
\text { предприятий вокруг } \\
\text { крупной компании }\end{array}$ & $\begin{array}{l}\text { Электротехнический, } \\
\text { автомобильный и др. }\end{array}$ \\
\hline Финляндия & $\begin{array}{l}\text { 1. Формирование уровня } \\
\text { развития системы } \\
\text { взаимодействия научных } \\
\text { институтов и отраслей } \\
\text { 2. Вложение в сферу } \\
\text { развития человеческого } \\
\text { потенциала }\end{array}$ & $\begin{array}{l}\text { Взаимодействие } \\
\text { крупных, средних и } \\
\text { малых предприятий. }\end{array}$ & $\begin{array}{l}\text { Лесной, } \\
\text { информационный, } \\
\text { телекоммуникационный, } \\
\text { металлургический, } \\
\text { машиностроительный и } \\
\text { др. }\end{array}$ \\
\hline Франция & $\begin{array}{l}\text { 1. Ц Централизованное } \\
\text { регулирование } \\
\text { инновационной } \\
\text { деятельности } \\
2 . \quad \text { Стимулирование } \\
\text { НИОКР для нужд } \\
\text { промышленности } \\
\text { 3. Бюджетные } \\
\text { ассигнования наукоёмких } \\
\text { видов бизнеса } \\
4 . \quad \text { Снижение налога на } \\
\text { инвестиции НИОКР }\end{array}$ & $\begin{array}{l}\text { Концентрация } \\
\text { предприятий вокруг } \\
\text { крупной компании }\end{array}$ & $\begin{array}{l}\text { Парфюмерно- } \\
\text { космический, } \\
\text { текстильный, пищевой, } \\
\text { винодельческий и др. }\end{array}$ \\
\hline Германия & $\begin{array}{l}\text { 1. Поощрение Развития } \\
\text { высоких Технологий } \\
2 . \text { Поощрение } \\
\text { консолидации усилий } \\
\text { промышленности научных } \\
\text { центров } \\
\text { 3. Финансирование } \\
\text { промышленных кластеров } \\
\text { из федеральных и местных } \\
\text { источников } \\
4 . \quad \text { Законодательное } \\
\text { регулирование рынка труда }\end{array}$ & $\begin{array}{l}\text { Взаимодействие } \\
\text { крупных, средних и } \\
\text { малых предприятий }\end{array}$ & $\begin{array}{l}\text { Химический, } \\
\text { полиграфический, } \\
\text { машиностроительный, } \\
\text { электрооборудование, } \\
\text { мебельный и др }\end{array}$ \\
\hline
\end{tabular}

Источник: Бузина стат.

Источник: Сайт компании Nano technology news network 
С учётом мирового опыта совершенствование текстильного кластера в Узбекистане должно идти в направлении развития межотраслевой и межтерриториальной кооперации в сфере текстильной и швейной промышленности. Включение в этот кластер нефтегазохимических комплексов и химической промышленности позволит сформировать единую технологическую цепочку создания нового конкурентоспособного текстильного продукта на основе использования химических волокон и нитей. Параллельно следует развивать институт моды, научные и консультационный центры лёгкой промышленности и координационный центр кластера (по опыту Турции). Эти центры могут оказывать такие услуги как профильное обучение, исследования в области технологий и материалов, исследования рынков одежды, развития экспорта, управление интеллектуальной собственности, бренд менеджмент, развитие персонала, управление качеством, посредничество при организации совместных предприятий представителями малого бизнеса.

В качестве стимула к созданию отечественных высоких технологий необходимо увеличить затраты на научные исследования и разработки до 2,5-2,9\% ВВП. В настоящее время затраты на НИОКР составляют $0.1 \%$. При этом доля собственных средств организации в общем объёме затрат на научные исследования и разработки должна составлять не менее $52-54 \%$, важная роль должна быть отведена научно-производственным объединениям, позволяющим сформировать сквозной технологический цикл: исследование-разработка-производствореализация продукции. Это будет способствовать достижению конкурентоспособности на мировых рынках наукоёмкой продукции.

\section{ЛИТЕРАТУРА}

1. Развитие кластеров: сущность, актуальные подходы, зарубежный опыт. С.Ф. Пяпенкин, Т.П. Быкова, Минск: Тесей, 208-72 стр.

2. «Совершенствование структурных преобразований текстильной промышленности в условиях инновационного развития Узбекистана»- С.М. Каримов, автореферат диссертации на соискание научной степени. 